\title{
Strategic Library Assessment: Aligning with your University's Strategic Plan
}

\author{
Kathryn M. Crowe \\ University of North Carolina at Greensboro, USA
}

\section{Introduction}

Demonstrating academic libraries' value has been an important initiative in the profession since the publication of ACRL's The Value of Academic Libraries in 2010. This report encouraged libraries to become more closely aligned with their institutions' mission and goals as a mechanism to show their value and contributions to their campuses. Because academic libraries do not exist in a vacuum, but are part of their academic institutions, it is essential that they understand the institutional mission and align services and resources with them and communicate this alignment widely. As stated in the document, "Communicating that alignment is crucial for communicating library value in institutional terms." ${ }^{1}$ Furthermore, academic libraries should let the institutional mission guide their assessment initiatives, an approach that provides libraries additional opportunities to show their value to their campus through good data. ${ }^{2}$

More recently, in its 2017 report, ACRL Academic Library Impact: Improving Practice and Essential Areas to Research, ACRL further recommended that libraries:

- Match library assessment to institution's mission

- Include library data in institutional data collection ${ }^{3}$

The Impact report also recommended that libraries participate in the data environment used by their academic institution in order to report their accomplishments. ${ }^{4}$

And, in ACRL's new Standards for Libraries in Higher Education (2018), the Association included the following as performance indicators for the Institutional Effectiveness principle:

- The library defines and measures outcomes in the context of institutional mission.

- The library develops outcomes that are aligned with institutional, departmental, and student affairs outcomes. $^{5}$

These guidelines confirm that academic library administrators and assessment librarians need to align strategic planning and assessment efforts with their university's planning operations as an important strategy to show the library's value and contributions to the campus.

The University of North Carolina at Greensboro (UNCG) is a high research activity campus with an enrollment of 20,000 that is part of the 17-campus University of North Carolina system. In fall 2016, the new chancellor began a strategic planning process. The university libraries participate actively in this process each year by submitting goals and metrics and aligning them with the university's strategic plan in the campus data system. This article presents a case study to illustrate how an academic library can demonstrate its value by developing assessments and strategic plans that support the university's mission.

\section{Literature Review}

Even before ACRL's value study, librarians began calling for academic libraries to align with their campus mission. Dillon stated in No Brief Candle: Reconceiving Research Libraries for the $21^{\text {st }}$ Century (2008), "Academic libraries will survive as long as there are universities. However, libraries cannot thrive without aligning their workings directly to the core mission of their host institutions." ${ }^{6}$

More recent studies indicate a disconnect between academic libraries and their institutions' goals and mission. The 2016 Ithaka S\&R Library Survey included responses from 722 academic library directors from all types of institutions. The results suggested that directors and their provosts do not always share the same 
vision of the library's mission. Those respondents that indicated they had a well-developed strategic plan, however, felt they were more integrated with the institution's senior leadership than those who did not have a solid plan. ${ }^{7}$ For ACRL's Impact study mentioned above, the researchers interviewed 14 provosts from a variety of institutions. Outcomes of these interviews revealed that communication is essential and that library administrators need to make provosts aware of library efforts that align with institutional mission and goals. Library administrators also need to employ the terminology used by provosts and other university administrators. $^{8}$

In a study published in 2018, Murray and Ireland surveyed provosts at institutions from master's level or above to determine how they perceive academic libraries as playing a role with issues of institutional importance, what types of data they find useful, and what methods of communication are successful to increase library funding. Results showed that demonstrated correlations linking the use of library services and resources with academic success, retention and enrollment, and faculty research productivity were the most important for funding requests. Other types of useful information included use data, user satisfaction, qualitative data, and information literacy student learning outcome data. ${ }^{9}$ Respondents indicated that the most helpful communication tool for budgeting was the formal annual report followed by budget presentations or meetings. Endorsements from other deans and administrators were also noted as influential. ${ }^{10}$ The authors concluded, "Academic libraries are no longer the symbolic "heart of the university; instead, they must provide evidence to support funding requests that support the priorities of the institution as a whole." ${ }^{11}$

In other recent studies, researchers sought to determine how academic libraries use assessment to inform their strategic plans and align with their institution. In 2018, Miller conducted an exploratory study by surveying libraries in Australia, Canada, and the UK to determine how university libraries engage with their university community when developing strategic plans. Respondents expressed that libraries use a variety of methods with surveys being the most popular followed by focus groups, interviews, and consultations. ${ }^{12}$ Also in 2018, Springmier, Edwards, and Bass explored how academic libraries use data and strategic planning documents to communicate with their stakeholders and others with the hypothesis that a strong commitment to assessment would correlate with the presence of data on the library's website. The authors conducted a content analysis of 97 North American websites and scored them with a rubric. Of these libraries, $57 \%$ made data available to the public with the most usual being "counting" statistics of volumes held, classes, gate counts, etc. Libraries that scored higher on their evaluation also provided benchmarks or comparisons. The most effective strategies used data to tell the story of the library and communicate its impact on the campus. These libraries devoted a section of their website to assessment and provided archived documents of initiatives. ${ }^{13}$ Madsen and Hurst with Athenaeum21 Consulting conducted 96 interviews with library administrators from the United States, the United Kingdom, and Germany between 2015 and 2017 to examine the landscape of library assessment and the culture of assessment in academic libraries. Their inquiry included exploring the relationship between assessment and the library's strategic plan, how the library's assessment tied into the parent institution's plan, and the importance of integrating with the institution's assessment operation. They also conducted a survey in 2017 with 211 assessment librarians and other administrators completing it. The libraries in this study reported that assessment activities were closely tied to their strategic planning; fewer libraries, however, reported a strong link with their university's strategic planning. ${ }^{14}$ The authors recommended that, with the current progression toward impact assessment as opposed to service quality improvement, libraries need to better align assessment to their institutions priorities; also, libraries need to pair their data with better reporting tools and link it directly to both the library's and institution's mission and goals. ${ }^{15}$

A few librarians have published articles specifically about tying assessment to library and campus strategic planning efforts. Franklin discussed such activity at the University of Connecticut. In 2009, the university launched a new strategic plan and each academic unit was charged with adapting its plan to support that of the university. ${ }^{16}$ The library's planning team developed its strategy and used LibQUAL ${ }^{\circledR}$ data as supporting documentation. Goals, measures, and metrics were defined that directly followed the university's guidelines ${ }^{17}$ In a follow-up article in 2012, Franklin noted the impact of these efforts on the library. The new strategic plan influenced a reorganization of the library and assessment data tracked growth and changes for 
each goal of the strategic plan, thus showing how the library supported the university's mission. ${ }^{18}$ Also, the LibQUAL survey administered after changes were made showed improvement in service quality scores. ${ }^{19}$ Walter provided a case study in 2018 that discussed aligning across university units to promote awareness of the library's value. The library at DePaul University adopted the university's strategy for its own 2012-18 plan and focused on initiatives relating to teaching and learning associated with academic quality and educational innovation. They used data from the Ithaka Local Faculty S\&R Survey to demonstrate that DePaul faculty perceived the library as important to their teaching and developing undergraduate critical thinking and information literacy skills. ${ }^{20}$ Walter also reported that the library is in the process of integrating with the campus learning analytics system. ${ }^{21}$ In another 2018 study, Britto and Kinsley described using a logic model to develop the libraries' strategic plan at the University of Florida to submit to the university's institutional effectiveness plan. ${ }^{22}$ Library units were asked to develop assessment measures to demonstrate to stakeholders how they contributed to the university's mission. ${ }^{23}$

\section{Case Study}

The University of North Carolina at Greensboro (UNCG) is a high research activity university with an enrollment of 20,000 students and part of the 17-campus University of North Carolina system. In fall 2016, the new chancellor began a strategic planning process with a focus on "big ideas" and "giant steps." The strategic plan employs a framework that emphasizes student, knowledge, and regional transformation in three areas of focus: Health and Wellness, Vibrant Communities, and Global Connections:

Table 1

\begin{tabular}{|l|l|}
\hline Areas of Transformation & Areas of Focus \\
\hline Student Transformation & Vibrant Communities \\
\hline Knowledge Transformation & Health \& Wellness \\
\hline Global Connections & Regional Transformation \\
\hline
\end{tabular}

Each year, specific goals and key performance indicators with metrics are identified for each of the areas of transformation and foci. ${ }^{24}$ The plan also follows the five areas identified in the strategic plan for the University of North Carolina system, which include access, affordability and efficiency, student success, economic impact and community engagement, and excellent and diverse institutions. ${ }^{25}$

\section{University Libraries Strategic Planning Process}

The UNCG Libraries, while they do have an established mission along with goals and values, do not have a long-term strategic plan; instead, an annual strategic plan is developed each year. ${ }^{26}$ The process begins with a retreat of the leadership group that includes the dean, assistant deans, and all department heads. This group develops an initial plan that the dean and assistant deans then finalize at another retreat. Each goal includes action items with assigned responsibility, metrics, and targets, and indicates which aspect of the UNCG plan it supports. This plan forms the basis of what is then entered in the template required by the Office of Assessment and Accreditation. Figure 1 illustrates this process. 


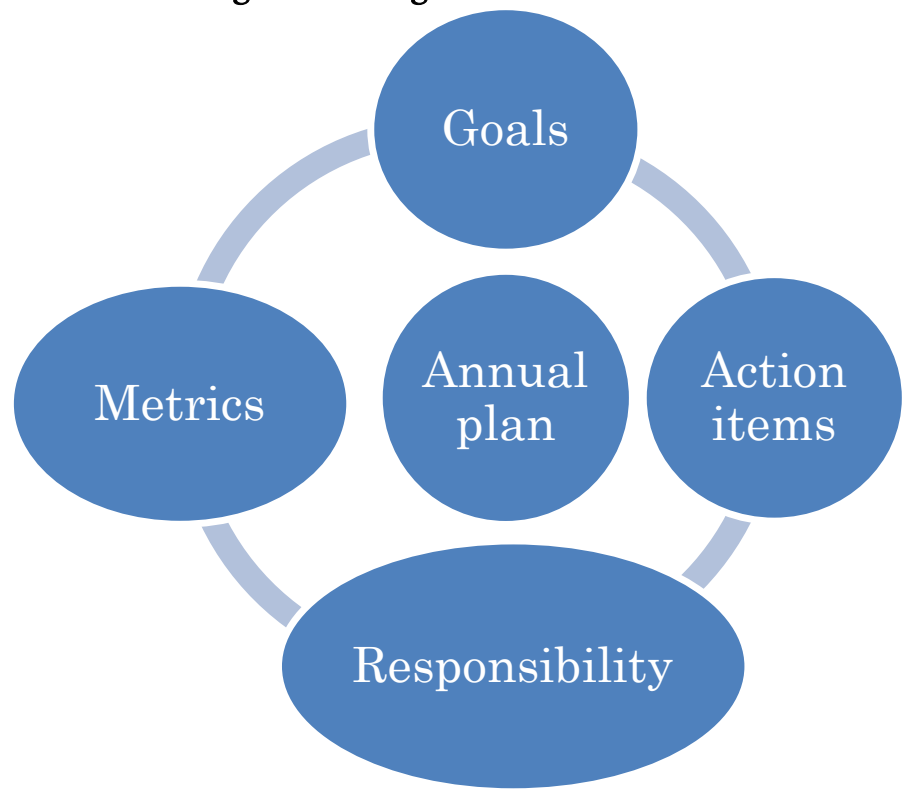

\section{UNCG Strategic Planning Process}

UNCG's Office of Accreditation and Assessment (OAA) is charged with organizing and implementing the annual strategic planning process. All academic and administrative units are required to submit their strategic plan (formerly called the institutional effectiveness plan) for the upcoming year to this office with identified objectives, measures, and targets. The units' mission statements are also included. This plan emphasizes change and improvement. At the end of the year, units submit a strategic planning report with findings to show if these objectives were accomplished or not along with analysis and explanations. This report also requires an action plan to show how the unit will follow up on their findings. Activities may also be recorded. Figure 2 illustrates this process. The libraries have participated in this process since 2008 and a member of the libraries' faculty has served on the UNCG Institutional Effectiveness Committee since then as well. ${ }^{27}$ The libraries' goals and metrics for the year that specifically show change and improvement form the measures and targets for the strategic plan submitted to OAA. 
Figure 2 UNCG Strategic Planning Process

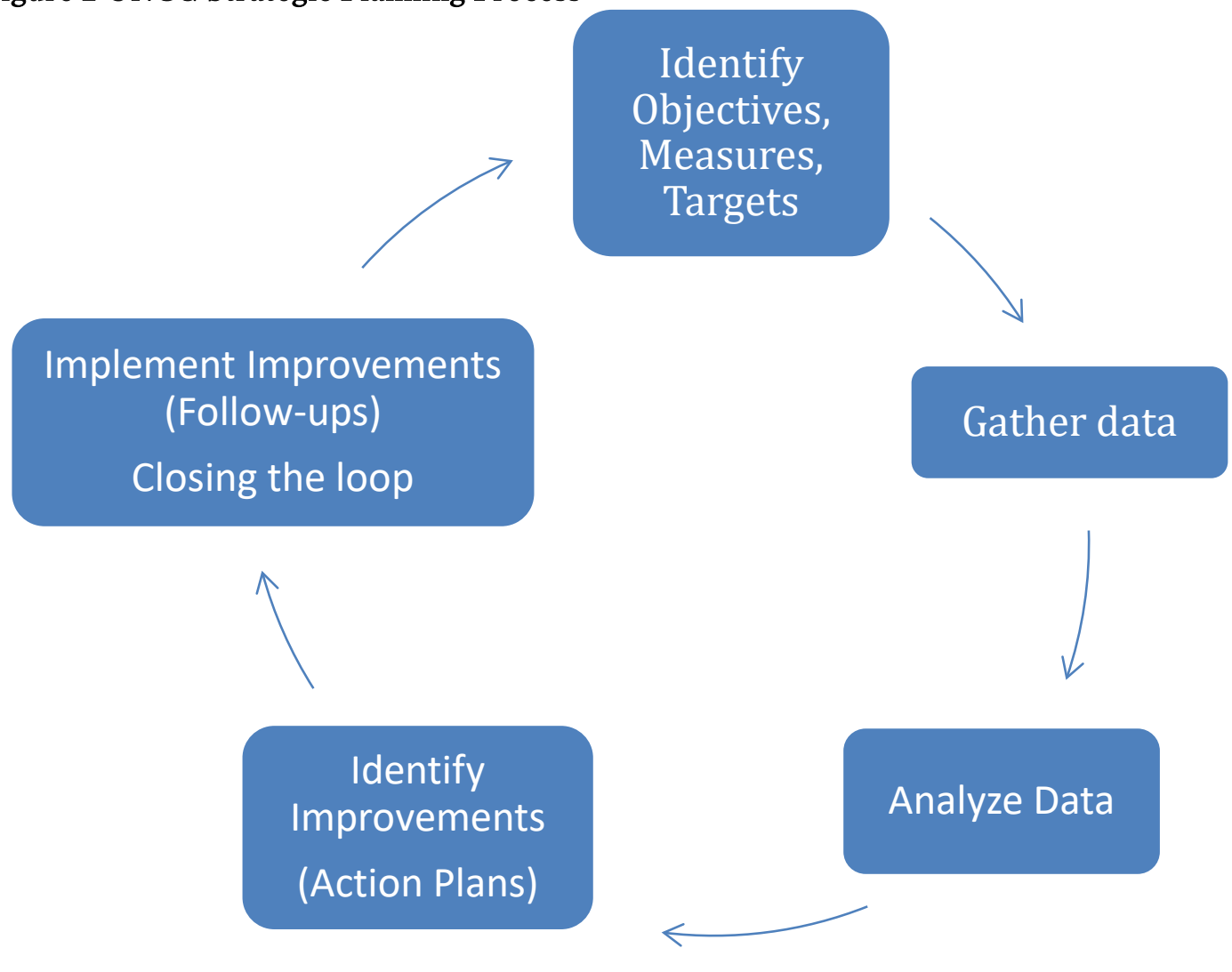

Beginning in 2016, all UNCG units were asked to link their goals to the new UNCG strategic planning framework. The libraries determined that most of our goals aligned with the student and knowledge areas of transformation and the vibrant communities focus area. The chancellor's office developed a report, Giant Steps: Initiatives Supporting Transformation of Students, Knowledge, and the Region. ${ }^{28}$ It was very gratifying that most of the libraries' initiatives were included in this campus-wide report thus showing how the libraries align with the UNCG strategic plan. This report is kept current so that unit goals continue to be showcased.

To incentivize the strategic plan, the university offered faculty seed grants in 2016-17 for teaching innovations, research, and community-engaged research. ${ }^{29}$ The libraries' digital projects unit received a research grant in collaboration with history and library and information studies (LIS) faculty. The libraries' digital project, North Carolina Runaway Slave Advertisements, 1750-1865, was incorporated into a capstone history course and LIS students had the opportunity to learn how to digitize primary source materials. ${ }^{30}$ This grant provided another opportunity for the libraries to integrate and align with the UNCG strategic plan.

\section{Integrating the Libraries' Strategic Planning with the University's Plan}

Moving forward, the libraries' 2017-18 strategic plan included several goals that supported the UNCG framework and demonstrated value. The following table provides an example of how the libraries' planning cycle aligned with the UNCG strategic plan: 
Table 2

\begin{tabular}{|c|c|c|c|c|}
\hline $\begin{array}{l}\text { Selected } \\
\text { Objectives }\end{array}$ & Measures & Targets & Findings & $\begin{array}{l}\text { Link to UNCG } \\
\text { Framework }\end{array}$ \\
\hline $\begin{array}{l}\text { Make UNCG an } \\
\text { OER leader within } \\
\text { the state in order } \\
\text { to reduce the cost } \\
\text { of a college } \\
\text { education for our } \\
\text { students }\end{array}$ & $\begin{array}{l}\text { Number of } \\
\text { adopted course } \\
\text { textbooks freely } \\
\text { provided online } \\
\text { Amount of student } \\
\text { savings if they } \\
\text { don't purchase the } \\
\text { text }\end{array}$ & $\begin{array}{l}\text { Provide at least } \\
200 \text { texts } \\
\text { Students savings of } \\
\text { at least } \$ 200,000 \text { if } \\
\text { they don't } \\
\text { purchase the text }\end{array}$ & $\begin{array}{l}532 \text { course texts } \\
\text { provided as e- } \\
\text { books with a } 55 \% \\
\text { increase from } 16- \\
17 \\
\text { Potential savings } \\
\text { of } \$ 445,643\end{array}$ & $\begin{array}{l}\text { Vibrant Communities } \\
\text { Student } \\
\text { Transformation } \\
\text { Knowledge } \\
\text { Transformation } \\
\text { Regional } \\
\text { Transformation }\end{array}$ \\
\hline $\begin{array}{l}\text { Develop a master } \\
\text { space plan for } \\
\text { Jackson and } \\
\text { Schiffman } \\
\text { Libraries in order } \\
\text { to maximize space } \\
\text { for services, } \\
\text { learning, and } \\
\text { unique materials }\end{array}$ & $\begin{array}{l}\text { Number of seats } \\
\text { added }\end{array}$ & $\begin{array}{l}60 \text { seats added on } \\
5 \text { th floor by June } \\
2018\end{array}$ & 72 new seats added & $\begin{array}{l}\text { Vibrant Communities } \\
\text { Student } \\
\text { Transformation } \\
\text { Knowledge } \\
\text { Transformation }\end{array}$ \\
\hline $\begin{array}{l}\text { Undertake an } \\
\text { information } \\
\text { fluency initiative } \\
\text { in order to expand } \\
\text { information } \\
\text { literacy/fluency on } \\
\text { campus and in the } \\
\text { community }\end{array}$ & $\begin{array}{l}\text { Difference in GPA } \\
\text { between students } \\
\text { who receive } \\
\text { library instruction } \\
\text { and those that do } \\
\text { not. }\end{array}$ & $\begin{array}{l}\text { Difference in GPA } \\
\text { between those that } \\
\text { receive library } \\
\text { instruction and } \\
\text { those who do not } \\
\text { of at least } 0.25 \\
\text { Number of } \\
\text { community } \\
\text { workshops } \\
\text { Number of faculty } \\
\text { development } \\
\text { stipends to } \\
\text { restructure a } \\
\text { course }\end{array}$ & $\begin{array}{l}\text { The overall } \\
\text { difference for all } \\
\text { subjects was } 0.27 \\
\text { (an average GPA of } \\
2.87 \text { for those who } \\
\text { did not receive } \\
\text { instruction and } \\
3.14 \text { for those who } \\
\text { did) }\end{array}$ & $\begin{array}{l}\text { Vibrant Communities } \\
\text { Student } \\
\text { Transformation } \\
\text { Knowledge } \\
\text { Transformation }\end{array}$ \\
\hline
\end{tabular}

\section{Integrating Assessment with Strategic Planning}

The university libraries' assessment program is coordinated by a team. This group establishes an annual plan based on current needs, goals, and initiatives from around the libraries. Team members as well as other librarians and staff engage in assessment projects. Support for the program is provided by a graduate student and staff from UNCG's Office of Assessment, Evaluation and Research Services (OAERS), a service of the School of Education's educational research methodology department. This plan is presented to libraries' 
leadership for approval. Results, reports, presentations, and publications about all assessment projects are posted on a LibGuide along with a summary report at the end of each year. ${ }^{31}$

Several assessment studies provided data for building and future renovation plans. The Harold Schiffman Music Library, a branch in the music building, has underutilized space in its lower level. A needs assessment conducted in the School of Music in 2016-17 provided evidence that students needed more recording space. The libraries are working with the school to develop renovation plans to provide such a space that will help students' success in making recordings to submit for graduate school and performance opportunities. For the past few years, the libraries have engaged in a "rightsizing" project to reduce the stack footprint and increase seating and learning spaces. Observational studies of both technology and furniture have informed placement and purchases of both. In addition, the libraries are in the process of developing a master plan for a major renovation and addition. Building results from a general student survey in 2017 provided evidence of student needs and desires for learning spaces and technology to enhance their success. An infographic and other handouts were developed to provide brief bullet points for the project architects and university administrators. More recent assessments in the libraries' Digital Media Commons will provide useful information about how space and services will inform the master space plan.

As frequently noted in assessment literature, other studies provided evidence of the need for marketing resources and services. A 2017 survey conducted among distance learning students indicated that many are not aware of the libraries' extensive online resources and services. Similarly, a survey of students who study abroad showed that they, too, did not use the libraries' online resources or chat service while in another country. As a result, a marketing campaign is part of the libraries' plan for 2018-19.

A frequent theme in library value literature is to measure the library's impact on student success by determining if library use affects student grades or other standard criteria. The UNCG Libraries conducted a grade study in 2017-18 that compared the aggregate GPA of students in 100-level classes who attended a library instruction class to those who did not. The results were positive overall as noted in the above table. In the discussions of the findings with the OAERS consultants, however, it was determined that there are too many variables with student grades and it is very difficult to make a direct correlation to the library's influence. With this end in mind, the libraries' assessment team decided to focus on authentic assessment of student work in the future following the libraries' student learning goals based on ACRL's Information Literacy Framework.

The table below illustrates how the libraries' assessment informs strategic planning and thus aligns with the university's mission and planning:

Table 3

\begin{tabular}{|l|l|l|}
\hline Assessment project & $\begin{array}{l}\text { Libraries' Strategic Plan Action } \\
\text { Item }\end{array}$ & Link to UNCG Framework \\
\hline $\begin{array}{l}\text { Needs assessment of Schiffman } \\
\text { Music Library. Surveyed School } \\
\text { of Music students \& held focus } \\
\text { groups }\end{array}$ & $\begin{array}{l}\text { Renovate space to provide a } \\
\text { recording studio needed by } \\
\text { students }\end{array}$ & Vibrant Communities \\
Student Transformation \\
\hline $\begin{array}{l}\text { Digital Media Commons } \\
\text { assessment. Surveyed faculty and } \\
\text { customers and held student focus } \\
\text { groups }\end{array}$ & $\begin{array}{l}\text { Informed future planning of } \\
\text { DMC }\end{array}$ & Vibrant Communities \\
Informed Master Space Plan & Student Transformation \\
\hline
\end{tabular}




\begin{tabular}{|c|c|c|}
\hline Assessment project & $\begin{array}{l}\text { Libraries' Strategic Plan Action } \\
\text { Item }\end{array}$ & Link to UNCG Framework \\
\hline $\begin{array}{l}\text { Distance Learning survey } \\
\text { Study Abroad survey }\end{array}$ & $\begin{array}{l}\text { Developed a marketing plan to } \\
\text { publicize remote and electronic } \\
\text { services and resources more } \\
\text { effectively }\end{array}$ & $\begin{array}{l}\text { Vibrant Communities } \\
\text { Student Transformation } \\
\text { Knowledge Transformation }\end{array}$ \\
\hline $\begin{array}{l}\text { Technology use data and } \\
\text { observations }\end{array}$ & $\begin{array}{l}\text { Determined future technology } \\
\text { purchases and their placement }\end{array}$ & $\begin{array}{l}\text { Vibrant Communities } \\
\text { Student Transformation } \\
\text { Knowledge Transformation }\end{array}$ \\
\hline $\begin{array}{l}\text { Student surveys-building } \\
\text { responses }\end{array}$ & Informed Master Space Plan & $\begin{array}{l}\text { Vibrant Communities } \\
\text { Student Transformation } \\
\text { Knowledge Transformation }\end{array}$ \\
\hline Furniture use observations & $\begin{array}{l}\text { Provided additional seating and } \\
\text { effective learning spaces }\end{array}$ & $\begin{array}{l}\text { Vibrant Communities } \\
\text { Student Transformation } \\
\text { Knowledge Transformation }\end{array}$ \\
\hline Student grade study & $\begin{array}{l}\text { Determined decision to focus on } \\
\text { authentic assessment of student } \\
\text { work and conduct more robust } \\
\text { analysis of LibInsight data }\end{array}$ & $\begin{array}{l}\text { Vibrant Communities } \\
\text { Student Transformation } \\
\text { Knowledge Transformation }\end{array}$ \\
\hline
\end{tabular}

\section{Conclusion and Recommendations}

In recent years, hundreds of useful and important studies have been published that provide research and protocols for academic libraries on how they can demonstrate their value to their campuses. ACRL has led this effort and provided excellent support and guidance through funding, documents, and infrastructure. Few publications, however, focus specifically on how libraries' assessment data can match with their institutions' mission and, in turn, align and support the university's mission and strategic plan as recommended by ACRL in its Impact report. It is important to participate in campus planning and assessment committees and integrate with the university data system. This case study provides an example of how an academic library can demonstrate its value to the university by integrating and aligning with the campus strategic planning and assessment process. Effective assessment shows that the libraries are providing good data for planning and follow-up and are thus furthering UNCG's goals and mission. The libraries are fortunate to be fully integrated with the campus-wide planning and assessment process. Recent developments where unit accomplishments are documented in the campus data system have enhanced the libraries' profile. Over the years, the libraries have learned to merge its planning and reporting more 
effectively with the university's process and are thus able to show how they support and enhance UNCG's mission.

-Copyright 2019 Kathryn M. Crowe

\section{Endnotes}

1. Association of College and Research Libraries, The Value of Academic Libraries: A Comprehensive Research Review and Report, prepared by Megan Oakleaf (Chicago: Association of College and Research Libraries, 2010), 30.

2. ACRL, Value of Academic Libraries, 29-10, http://www.ala.org/acrl/sites/ala.org.acrl/files/content/issues/value/val_report.pdf.

3. Association of College and Research Libraries, Academic Library Impact: Improving Practice and Essential Areas to Research, Prepared by Lynn Silipigni Connaway, William Harvey, Vanessa Kitzie, and Stephanie Mikitish (Chicago: Association of College and Research Libraries, 2017), 1, http://www.ala.org/acrl/sites/ala.org.acrl/files/content/issues/value/val_report.pdf.

4. ACRL, Academic Library Impact, 54-55.

5. Association of College and Research Libraries, Standards for Libraries in Higher Education (Chicago: Association of College and Research Libraries, 2018), 10.

6. Andrew Dillon. "Accelerating Learning and Discovery: Refining the Role of Academic Librarians," in No Brief Candle: Reconceiving Research Libraries for the 21st Century (Washington, DC: Council on Library and Information Resources, 2008), 57.

7. Christine Wolff-Eisenberg, US Library Survey 2016 (New York: Ithaka S\&R, 2016), 16-19.

8. ACRL, Academic Library Impact, 46-47.

9. Adam Murray and Ashley Ireland, "Provosts' Perceptions of Academic Library Value \& Preferences for Communication: A National Study,” College \& Research Libraries 79, no. 3 (2018): 13, https://crl.acrl.org/index.php/crl/article/view/16693/18647.

10. Murray and Ireland, "Provosts' Perceptions," 16-17.

11. Murray and Ireland, "Provosts' Perceptions," 31.

12. Laura Newton Miller, "University Community Engagement and the Strategic Planning Process," Evidence Based Library \& Information Practice 13, no. 1 (January 2018): 9, https://doi.org/10.18438/eblip29351.

13. Kaitlin Springmier, Elizabeth Edwards, and Michelle B. Bass, "Sharing Success: A Review of Strategic Planning, Annual Reports, and Publicly Available Information from Academic Libraries," Evidence Based Library \& Information Practice 13, no. 2 (June 2018): 72-77, https://doi.org/10.18438/eblip29316.

14. Christine Madsen and Megan Hurst, "Contextualizing Library Assessment within a Broader Ecosystem," Performance Measurement \& Metrics 19, no. 1 (January 2018): 20-23, https://doi.org/10.1108/PMM-092017-0042.

15. Madsen and Hurst, "Contextualizing Library Assessment," 27-28.

16. Brinley Franklin, "Aligning Library Strategy and Structure 2ith the Campus Academic Plan: A Case Study,” Journal of Library Administration 49, no. 5 (July 2009): 496, https://doi.org/10.1080/01930820903090862.

17. Franklin, “Aligning Library Strategy,” 499-501.

18. Brinley Franklin, "Surviving to Thriving: Advancing the Institutional Mission," Journal of Library Administration 52, no. 1 (January 2012): 98-102, https://doi.org/10.1080/01930826.2012.630244.

19. Franklin, "Surviving to Thriving," 105.

20. Scott Walter, "Communicating Value through Strategic Engagement," Library Management 39, no. 3/4 (April 2018): 157-158, https://doi.org/10.1108/LM-09-2017-0093.

21. Walter, "Communicating Value," 161. 
22. Marwin Britto and Kirsten Kinsley, Academic Libraries and the Academy: Strategies and Approaches to Demonstrate Your Value, Impact, and Return on Investment (Chicago, IL: Association of College \& Research Libraries, 2018), 120-121.

23. Britto and Kinsley, 132.

24. "Taking Giant Steps: The University of North Carolina at Greensboro Strategic Plan,” UNC Greensboro, accessed October 24, 2018, https://strategicplan.uncg.edu/core-elements/.

25. "Higher Expectations: The Strategic Plan for the University of North Carolina," UNC Greensboro, accessed October 24, 2018, http://www.northcarolina.edu/strategic-planning.

26. "The UNCG University Libraries' Mission, Goals and Values, UNC Greensboro," accessed October 24, 2018, http://library.uncg.edu/info/mission_statement.aspx.

27. The UNCG University Libraries' Strategic Planning reports are available at: http://uncg.libguides.com/c.php?g=83407\&p=535586.

28. "Giant Steps: Initiatives Supporting Transformation of Students, Knowledge, and the Region, UNC Greensboro," accessed October 25, 2018, https://strategicplan.uncg.edu/wpcontent/uploads/2017/09/table-document-with-initiatives-as-of-september-19-2017.pdf.

29. "Faculty Seed Grants," Taking Giant Steps, UNC Greensboro, https://strategicplan.uncg.edu/seedgrants/.

30. "North Carolina Runaway Slave Advertisements," UNC Greensboro, http://libcdml.uncg.edu/cdm/landingpage/collection/RAS.

31. UNCG University Libraries Assessment Information, UNC Greensboro, accessed October 24, 2018, http://uncg.libguides.com/libassessment. 